\title{
School-based Teacher Education with IT as a Tool
}

\author{
Palle Bendsen \\ Copenhagen Day and Evening College, Ejbyvej 25, 2740 Skovlunde, Denmark \\ palle.bendsen@skolekom.dk
}

Keywords: teacher education, tele-teaching, collaborative learning, curriculum changes, innovation

\begin{abstract}
In this study we used virtual tutoring and collaborative learning in a normal class of students in a Danish College of Education. Electronic guidance was established as an addition to traditional teaching. All students and teachers had a computer with Internet connection to an electronic conference system. Our experiences are that electronics increase the possibilities of collaboration, and electronic communication has an encouraging effect on learning and acquisition. The electronic tutorial style must be discussed with the students before and during the period of work. Electronic communication gives new possibilities for co-ordination of the teacher's mutual collaboration. Electronic communication leads to far more social and professional contacts among the participants than is the case in the usual student environment.
\end{abstract}

\section{VIRTUAL TUTORING AND COLLABORATIVE LEARNING}

Electronically tutoring (Veen et al. 1994, Collis 1994) is a useful and effective tool in the education of teachers because it is collective, open and in writing. Our experiences from four years of innovation experiments in teacher education (Bendsen et al. 1997) show the following:

- Electronics increase the possibilities of collaboration, because all students in a class can follow the professional communication at the same time. 
- Electronic communication has an encouraging effect on learning and acquisition because the students have to formulate their thoughts regarding professional and educational subjects.

- Telecommunication, combined with oral tutoring, will strengthen problem- and process-centred tutoring.

- The tele-tutorial, which is extremely quick, minimises time waste. It will be possible to work with clearly marked deadlines through an open control of the stages of the process.

- The electronic tutorial style has to be discussed thoroughly with the students before and during the period of work, because it may seem overwhelming far-reaching concrete and authoritative.

- Electronic communication gives new possibilities for co-ordinating teacher's mutual collaboration, as well as collaboration with the students.

- Electronic communication leads to more social and professional contacts among the participants than is the case in the usual student environment.

It is difficult to evaluate the importance of these different facts as a whole, but we think it improves social life and may increase the professional quality of the work.

\section{A REACTION TO THE CRITICISM OF DANISH TEACHER TRAINING}

It was, among other things, the Danish media's continuous criticism of the Folkeskole (municipal primary and lower secondary school) and the teacher education, which caused the Copenhagen Day and Evening College to establish a project supported economically by the CTU (Denmark's National Information Centre for Technology Supported Learning). The title of the project contains the two elements which form part of the purpose of the project: 'School-based Teacher Training with IT as a Tool' (Bendsen et al. 1997). With the use of the word 'school-based', we expressed our wish for a closer connection between theory and practice (Bendsen 1996) and 'IT as a tool' signals that the possibilities in IT could be exploited during the course at the same time. The intention was to look for new answers to the didactic and pedagogical problems that are presented in the education of teachers, both during the 6 weeks demonstration in a school (Bendsen 1996) and in the course itself. In addition, the students and we gained experience with the methodical and didactic application of IT.

The technical conditions were simple, as students and teachers were to have access at home to a PC and a modem. Those chosen were a group of students who had enrolled with the idea of working with IT related subjects 
during their education. But at the same time the group would meet with the teachers of different subjects every week according to a traditional timetable. This is not distance teaching.

The students' computer screen contained four different open teleconferences and a personal e-mail mailbox. The new concepts are as follows.

The Open conference system: - a forum which allows one-to-one or oneto-many communication. In particular, this provides the possibility for group communication or many-to-many debates. Everybody can make themselves heard and the writing (electronic mail) becomes the means of expression in a process which supplements and to a certain degree replaces the face-to-face communication (Dam1996).

The Tele-dialogue: - is the debates all students participate in. They are highly structured professional and pedagogical conferences, controlled by the teacher. They are based on practical problems that the students write about, during their meeting with the Folkeskolens' everyday life. We include some trainee teachers' participation in the tele-dialogue, citing their experiences of what we called: 'This weeks tele-theme'.

Collaborative learning (Sorensen 1996): - The thing that distinguishes collaborative communities from most other communities is a desire to construct new meanings about the world through interaction with others. The collaborative communities become a medium for both self-knowledge and self-expression. The collaborative situation is about how to be able to create new acquisition/learning jointly through their own experiences and arguments through confrontation with other people's opinions and attitudes.

\section{TUTORING IN VIRTUAL SPACE}

During a co-operation project called School and Society, the electronic tutoring was tested. As a starting point we agreed on the following:

- A set time frame.

- Method of work: a group-based project with the teachers as tutors and educators. The method of work contained the formulation of a problem with a delimited subject, a purpose, division of work, timing etc., plus the choice of method and arranged presentation for the whole class, all put down in a written report.

- All students could ask for a face-to-face tutorial with their teacher, but usually the teacher gave written response in the virtual conference.

- The application of collaborative learning was a process in which all student groups mailed their provisional theme problem, at the same time, to the common professional and pedagogical conference. 
Our intention in creating this comprehensive scope, including the teachers' co-ordinated response, was that the collaborative learning described should contribute something new, something different, and enable broader learning through a common construction of knowledge and inspiration in relation to the theme, School and Society. The subsequent exchange of experiences was an element of the collaborative learning, in the sense that it is interesting and exciting for the motivated student and teacher to follow the professional dialogue between teachers and the student groups and among the students themselves. Naturally, the individual student could also suggest his own professional related contribution, which also happened. This suggests an openness and use of insight which does not usually occur in a course. The whole innovation has taken place as a cross-curricular sequence with the participation of the following subjects: Danish language, psychology, pedagogy, social science, arts and religious instruction.

\section{REFERENCES}

Bendsen, P. et al. (1997) Skolebaseret loereruddannelse med ikt som arbejdsredskab. Rapport nr. 1 and 2, Copenhagen Day and Evening College, Copenhagen.

Dam, E. (1996) Moderator eller ordstyrer. Copenhagen Day and Evening College, Copenhagen.

Veen, W. et al. (1994) Tele-tutoring in Teacher Education. Journal of Information Technology and Teacher Education.

Collis B. (1994) New Possibilities for Teacher Education Through Computer-Based Communication Technologies. University of Twente, The Netherlands.

Bendsen P. (1996) Hvad lærer de studerende i praktikken? - refleksion som metode. Kalejdoskop, Copenhagen Day and Evening College, Copenhagen.

Sorensen, E. K. (1996) Kommunikation og loering i den virtuelle skole. Manus, Aarhus University.

\section{BIOGRAPHY}

Palle Bendsen is a specialist in pedagogical psychology and has participated in several research and evaluation projects. He was the leader of the first IT-classes in the Danish teacher training classes in the College of Education: Copenhagen Teacher Training College. 